\title{
UPAYA PENINGKATAN EKONOMI DAN PENGURANGAN SAMPAH DOMESTIK MASYARAKAT SUMBERSARI MELALUI PEMANFAATAN ALIRAN SUNGAI UNTUK BUDIDAYA IKAN MUJAIR
}

\author{
Romaidi $^{1}$, Bayu Agung Prahardika ${ }^{2}$, Muhammad Asmuni Hasyim ${ }^{3}$ \\ ${ }^{1,2,3}$ Jurusan Biologi, UIN Maulana Malik Ibrahim Malang \\ romaidi@bio.uin-malang.ac.id, bayu.agung.prahardika@bio.uin-malang.ac.id, \\ asmunimuhammad@bio.uin-malang.ac.id
}

\section{Info Artikel \\ Riwayat Artikel: \\ Diterima: Februari 2020 \\ Direvisi: Februari 2020 \\ Diterbitkan: Maret 2020}

\section{Keywords:}

Aquaculture

Fish

Karamba

River

\begin{abstract}
One of the biggest threats from human activities to rivers is the increasing number of residential areas around or even just above the river flow. This condition is certainly very threatening the sustainability of rivers in the region. One of the biggest threats is that the garbage produced by the community will be directly disposed of in the river flow. One way that can be done to reduce waste disposal in the river is by utilizing river flow, so that many rivers are now increasingly being developed as a vehicle for habitat conservation, because the river is considered important for various aquatic plants, migratory and sedentary fishes, and aquaculture ponds, birds and several types of mammals. In this case, the concept of river management must be based on environmental, ecological, economic and social aspects according to the characteristics of the surrounding community. The purpose of this community service is to utilize river flow for tilapia fish farming. The method used in the service is the PAR by way of lectures and direct practice in aquaculture with karamba by utilizing river flow. From the results of community service including partners showed that some respondents know how to fish with karamba, but do not know that river flow can also be used for fish farming with the karamba system. As well as the results of fish farming practices with the karamba system most of the respondents agreed agree (73\%) if the fish culture using the karamba system is used as an alternative business idea related to river flow utilization and $60 \%$ of respondents agree the use of river flow for fish cultivation can reduce waste disposal in the river.
\end{abstract}

Copyright $\odot 2020$ JRCE. All rights reserved.

\section{Korespondensi:}

Bayu Agung Prahardika,

UIN Maulana Malik Ibrahim Malang,

Jl. Gajayana No. 50 Malang, Jawa Timur, Indonesia 65144

bayu.agung.prahardika@bio.uin-malang.ac.id 


\section{PENDAHULUAN}

Air merupakan salah satu sumber daya alam yang paling dibutuhkan oleh semua makhluk hidup. Keberadaannya selalu menjadi kebutuhan penting dalam memenuhi segala bentuk aspek kehidupan. Oleh karena itu, perlu pemanfaatan air secara tepat guna dan bijaksana demi kepentingan generasi yang akan datang. Usaha penghematan dan perlindungan terhadap sumber atau mata air juga harus selalu diperhatikan. Usaha ini dimaksudkan untuk tetap menjaga kelestarian air tersebut bagi kelangsungan semua makhluk hidup. Hal ini dilakukan karena semakin banyaknya masalah yang menyebabkan kuantitas dan kualitas air menjadi tidak terjaga, salah satunya ialah akibat berbagai kegiatan dari manusia ataupun dari pencemaran secara alami yang berasal dari golongan alga yang mampu menghasilkan toksin.

Sungai adalah aliran air yang besar dan memanjang yang mengalir secara terus-menerus dari hulu (sumber) menuju hilir (muara). Sungai merupakan salah satu bagian dari siklus hidrologi. Air dalam sungai umumnya terkumpul dari presipitasi, seperti hujan, embun, mata air, limpasan bawah tanah, dan di beberapa negara tertentu juga berasal dari lelehan es/salju. Selain air, sungai juga mengalirkan sedimen dan polutan. Kemanfaatan terbesar sebuah sungai adalah untuk irigasi pertanian, bahan baku air minum, sebagai saluran pembuangan air hujan dan air limbah, bahkan sebenarnya potensial untuk dijadikan objek wisata sungai. Di Indonesia saat ini terdapat 5.950 daerah aliran sungai (DAS).

Pada saat ini, salah satu ancaman terbesar dari kegiatan manusia terhadap sungai adalah semakin banyaknya kawasan pemukiman yang berada di sekitar atau bahkan tepat diatas aliran sungai. Kondisi ini tentu sangat mengancam kelestarian sungai di kawasan tersebut. Sebab, kemungkinan besar sampah yang dihasilkan oleh masyarakat akan langsung dibuang di aliran sungai tersebut. Oleh karena itu, selain permasalahan eksploitasi yang berlebihan ternyata sungai juga masih mendapatkan ancaman lain yang juga berasal dari masyarakat di sekitarnya.

Sungai seringkali dikendalikan atau dikontrol supaya lebih bermanfaat atau mengurangi dampak negatifnya terhadap kegiatan manusia. Manajemen sungai merupakan aktivitas yang berkelanjutan, karena sungai cenderung untuk mengulangi kembali modifikasi buatan manusia. Saluran yang dikeruk akan kembali mendangkal, mekanisme pintu air akan memburuk seiring waktu berjalan, tanggul-tanggul dan bendungan sangat mungkin mengalami rembesan atau kegagalan yang dahsyat akibatnya. Keuntungan yang dicari dalam manajemen sungai seringkali "impas" bila dibandingkan dengan biaya-biaya sosial ekonomis yang dikeluarkan dalam mitigasi efek buruk dari manajemen yang bersangkutan. Sebagai contoh, di beberapa bagian negara berkembang, sungai telah dikungkung dalam kanal-kanal sehingga dataran banjir yang datar dapat bebas dan dikembangkan. Banjir dapat menggenangi pola pembangunan tersebut sehingga dibutuhkan biaya tinggi, dan seringkali makan korban jiwa. Sehingga banyak sungai yang kini semakin dikembangkan sebagai wahana konservasi habitat, karena sungai termasuk penting untuk berbagai tanaman air, ikan-ikan yang bermigrasi dan menetap, serta budidaya tambak, burung-burung dan beberapa jenis mamalia. Dalam hal ini, konsep manajemen sungai yang dilakukan harus berdasarkan aspek lingkungan, ekologi, ekonomi dan sosial sesuai karakteristik masyarakat di sekitarnya.

Perguruan Tinggi memiliki kewajiban untuk responsif dengan kondisi masyarakat sekitar. Tri Dharma Perguruan tinggi yaitu Pendidikan, Penelitian, dan Pengabdian kepada Masyarakat semuanya bermuara pada upaya memecahkan problem masyarakat, khususnya dengan program-program yang berkualitas. Program Pengabdian kepada Masyarakat ini adalah salah satu bentuk kegiatan yang langsung menyentuh dan diharapkan manfaatnya langsung dapat dimanfaatkan oleh masyarakat. Hal ini sangat selaras dengan tujuan dalam ajaran Islam yang senantiasa menganjurkan untuk tolong menolong, berbuat baik dan meringankan beban orang yang kesulitan sebagaimana Firman Allah Subhanahuwata'ala:

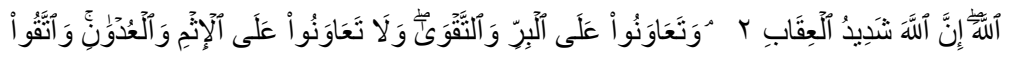

“..... dan tolong-menolonglah kamu dalam (mengerjakan) kebajikan dan takwa, dan jangan tolongmenolong dalam berbuat dosa dan pelanggaran, dan bertakwalah kamu kepada Allah, Sesungguhnya Allah Amat berat siksa-Nya (QS. Al-Maa'idah: 2)

Sebagai salah satu kawasan pemukiman yang padat di Kota Malang, kawasan Kelurahan Sumbersari masih banyak menghadapi kendala termasuk dalam pengelolaan aliran sungai yang mengalir di wilayahnya. Akibatnya sering terjadi banjir dan penumpukan sampah di sepanjang aliran sungai. Sungai yang mengalir di kelurahan Sumbersari masih termasuk dalam anak sungai DAS Brantas. Untuk itu diperlukan strategi pengelolaan secara terpadu dan berkelanjutan dari ekosistem sungai sebagai ekosistem perairan yang mengalir agar masyarakat di sekitar Kelurahan Sumbersari bisa merasakan secara langsung manfaat yang diberikan oleh sungai baik generasi saat ini maupun juga generasi yang akan datang. Selain itu, kawasan Kelurahan Sumbersari juga dikenal sebagai salah satu kawasan di Kota Malang yang memiliki

Peningkatan Ekonomi dan Pengurangan Sampah Domestik Masyarakat Sumbersari melalui Pemanfaatan Aliran Sungai untuk Budidaya Ikan Mujair (Bayu Agung Prahardika) 
industri kreatif paling banyak, seperti misalnya yang ditemukan di RW 1.

Masalah mendasar yang dihadapi dalam pengembangan pengelolaan ekosistem sungai di Kelurahan Sumbersari, khususnya di sekitar RW 1 adalah terbatasnya manajemen dan pengetahuan tentang konsep pemanfaatan sungai yang berbasis lingkungan dan berkelanjutan yang dimiliki oleh semua stakeholder, baik pemerintah maupun masyarakat. Perilaku membuang sampah sembarangan dan jumlah tempat sampah yang masih sedikit serta ditambah dengan tingkat kepedulian masyarakat terhadap kebersihan sungai yang masih rendah menyebabkan pengembangan pengelolaan ekosistem sungai menjadi jalan di tempat. Selain banyaknya aktifitas rumah kos mahasiswa, RW 1 yang terdapat di Kelurahan Sumbersari ini juga dikenal sebagai salah satu RW yang memiliki jumlah industri kreatif yang paling banyak dibandingkan RW yang lainnya. Kondisi ini tentu akan diimbangi dengan limbah hasil indusri yang dihasilkan. Oleh karena itu, anggapan sebagian besar masyarakat sekitar bahwa sungai adalah 'Tempat Sampah Terbesar' nantinya juga tidak hanya mengancam keberlangsungan ekosistem sungai, tetapi juga akan mengurangi jumlah populasi organisme lokal yang mempunyai habitat aliran sungai tersebut. Maksud dan tujuan dari pengembangan pengelolaan aliran sungai ini juga dapat selaras dengan menjamin kelestarian dari lingkungan seperti halnya berikut: 1. Menjaga tetap berlangsungnya proses ekologis yang tetap mendukung sistem kehidupan, 2. Melindungi keanekaragaman hayati, serta 3. Menjamin kelestarian dan pemanfaatan spesies dan ekosistemnya.

\section{METODE PENELITIAN}

Masyarakat yang menjadi objek pengabdian dalam kegiatan ini adalah masyarakat yang tinggal di sekitar wilayah RW 1 Kelurahan Sumbersari Kota Malang. Pemilihan tempat untuk pengabdian ini didasari pada banyaknya aktivitas manusia disekitarnya. Selain dikenal sebagai salah satu tempat di Kota Malang dengan banyaknya jumlah industri kreatif, kawasan RW 1 Sumbersari juga dikenal sebagai area dengan rumah kos mahasiswa yang banyak, sehingga dikawatirkan akan mengancam kelestarian ekosistem sungai disekitarnya.

Kegiatan Pengabdian Masyarakat ini dilakukan dalam beberapa tahap metodologis meliputi identifikasi, pengorganisasian, penyuluhan dan pelatihan, dan evaluasi.

1. Tahap Identifikasi

Langkah ini diperlukan untuk melakukan identifikasi permasalahan yang dihadapi masyarakat dalam memanfaatkan sungai yang mengalir di sekitarnya. Dalam tahapan ini dilakukan diskusi dengan sebagian/seluruh masyarakat terkait pengembangan pengelolaan sungai dan nantinya akan menciptakan model pengelolaan sungai di Kelurahan Sumbersari secara berkelanjutan

2. Tahap Pengorganisasian

Tahap ini meliputi proses pengurusan ijin, penetapan waktu, tempat, pembiayaan, jumlah peserta, serta penyiapan materi dan peralatan yang berkaitan dengan program pengabdian.

3. Tahap Penyuluhan dan Pelatihan

Metode penyuluhan digunakan untuk memberi wawasan yang bersifat teoritis dan praktis tentang materi pengabdian yaitu pengelolaan ekosistem sistem secara terpadu. Proses aksi penyuluhan diberikan dalam bentuk ceramah, diskusi dan tanya jawab. Kegiatan demonstrasi dan praktek pembuatan dan aplikasi pengelolaan ekosistem sungai secara terpadu dilakukan secara bersama-sama baik oleh tim penyuluh (dosen UIN Maulana Malik Ibrahim Malang) dengan peserta kegiatan. Selanjutnya, konsep pengembangan pengelolaan aliran sungai di Kelurahan Sumbersari yang ingin dilakukan adalah sebagai berikut:

- Sistem pengelolaan budidaya jenis ikan mujair dengan menggunakan di aliran sungai

- Sosialisasi tentang pentingnya menjaga kebersihan sungai dalam rangka menghindarkan dari berbagai penyakit

- Membangun kesadaran masyarakat dalam pengelolaan aliran sungai dan sungai secara keseluruhan/terpadu. 


\section{HASIL DAN PEMBAHASAN}

\subsection{Hasil Studi Pustaka dan Survei}

Wilayah Kota Malang sebagai salah satu kawasan metropolitan di Jawa Timur memiliki 'magnet' tersendiri dalam menarik minat masyarakat untuk semakin banyak berdatangan. Selain suhu udara rata-rata yang relatif masih sejuk, bentang alam yang beragam dari dataran tinggi hingga dataran rendah seperti dari pegunungan hingga pantai, hingga potensi pengembangan perekonomian yang tinggi karena banyaknya potensi sekolah dan universitas yang menyebar di setiap penjuru Kota Malang. Sehingga wajar jika wilayah Malang Raya yang meliputi Kota Batu, Kota Malang dan Kabupaten Malang adalah destinasi wisata yang sejak dulu menjadi salah destinasi favorit yang banyak dikunjungi wisatawan.

Kawasan Kelurahan Sumbersari merupakan salah satu kawasan di Kota Malang. Kawasan ini sebagai salah satu pusat area pendidikan sesuai misi Kota Malang sebagai Kota Pendidikan di Jawa Timur (lihat Gambar 1). Selain dikelilingi oleh beberapa kampus ternama seperti Universitas Brawijaya, Universitas Negeri Malang dan UIN Maulana Malik Ibrahim Malang, kawasan Kelurahan Sumbersari juga terdapat sekolah-sekolah tingkat menengah antara lain SMA Negeri 8, SMA Muhammadiyah 02, SMK Muhammadiyah 03, SMP Negeri 4, SMP Laboratorium UM, dan SMP Muhammadiyah 06.

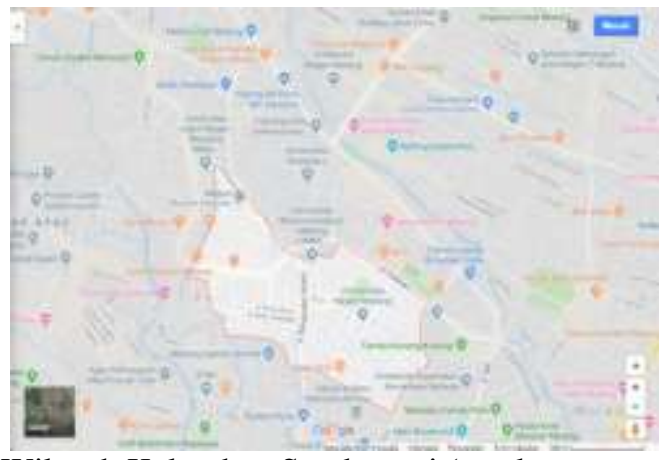

Gambar 1. Wilayah Kelurahan Sumbersari (petak warna merah muda)

Selain itu, tingginya arus penduduk yang masuk ke Kota Malang menjadi penyebab semakin banyaknya kawasan-kawasan pemukiman yang tidak terkontrol oleh pemerintah setempat. Kondisi ini jika dibiarkan tentunya akan mengancam keindangan Kota Malang yang dulunya dikenal dengan lingkungannya yang indah. Kelurahan Sumbersari merupakan kelurahan yang terletak di wilayah Kecamatan Lowokwaru, Kota Malang. Kelurahan ini terdiri dari 7 RW (Rukun Warga) dan 40 RT (Rukun Tetangga) (lihat Gambar 2). Secara administratif, Kelurahan Sumbersari dikelilingi oleh kelurahan lainnya yang ada di Kota Malang. Di sebelah utara, Kelurahan Sumbersari berbatasan langsung dengan Kelurahan Ketawanggede dan Kelurahan Dinoyo, Kecamatan Lowokwaru. Sedangkan di sebelah timur, kelurahan ini berbatasan langsung dengan Kelurahan Oro-oro Dowo dan Kelurahan Penanggungan, Kecamatan Klojen. Di sebelah selatan, Kelurahan Sumbersari berbatasan dengan Kelurahan Gadingkasri, Kecamatan Klojen dan Kelurahan Karangbesuki, Kecamatan Sukun. Lalu, di sebelah barat, Kelurahan ini berbatasan dengan Kelurahan Dinoyo, Kecamatan Lowokwaru dan Kelurahan Karangbesuki, Kecamatan Sukun. Kelurahan Sumbersari memiliki luas $1,28 \mathrm{~km}^{2}$, dan berada pada ketinggian $440 \mathrm{~m}$ dari atas permukaan laut. Suhu temperatur maksimum di wilayah kelurahan ini berkisar antara 25 hingga $32{ }^{\circ} \mathrm{C}$. Jumlah penduduk yang tercatat di kelurahan ini sekitar 14.661 jiwa, yang mayoritasnya memiliki usaha kos-kosan dan kuliner (warung makanan dan minuman).

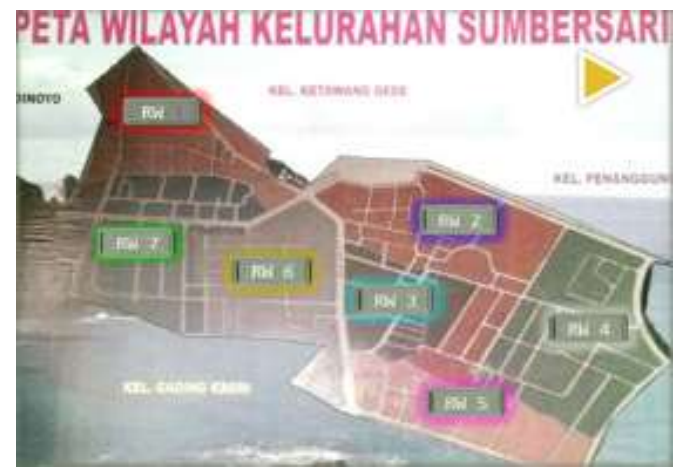

Gambar 2. Peta Persebaran RW di Wilayah Kelurahan Sumbersari 


\subsection{Gambaran Kegiatan}

Pelaksanaan kegiatan pengabdian ini sebagian besar adalah masyarakat sekitar Desa Sumbersari dan Mahasiswa dengan karakteristik usia pada masa dewasa sampai lansia sangat tepat mendapatkan materi mengenai pemanfaatan aliran sungai untuk budidaya ikan dengan tujuan untuk meningkatkan nilai ekonomi warga serta memberikan nilai edukasi terkait pentingnya menjaga kebersihan sungai dengan cara membuang sampah pada tempatnya. Pemanfaatan aliran sungai untuk budidaya ikan untuk meningkatkan nilai ekonomi dengan menggunakan sistem karamba. Metode pendampingan berupa ceramah dan edukasi mengenai 1) sistem budidaya ikan dengan karamba, 2) kelebihan metode budidaya ikan dengan sistem karamba, dan 3) manfaat menjaga ekosistem sungai untuk kehidupan yang lebih baik (Gambar 3 dan 4), rangkuman gambaran kegiatan ditampilkan pada Tabel 1.

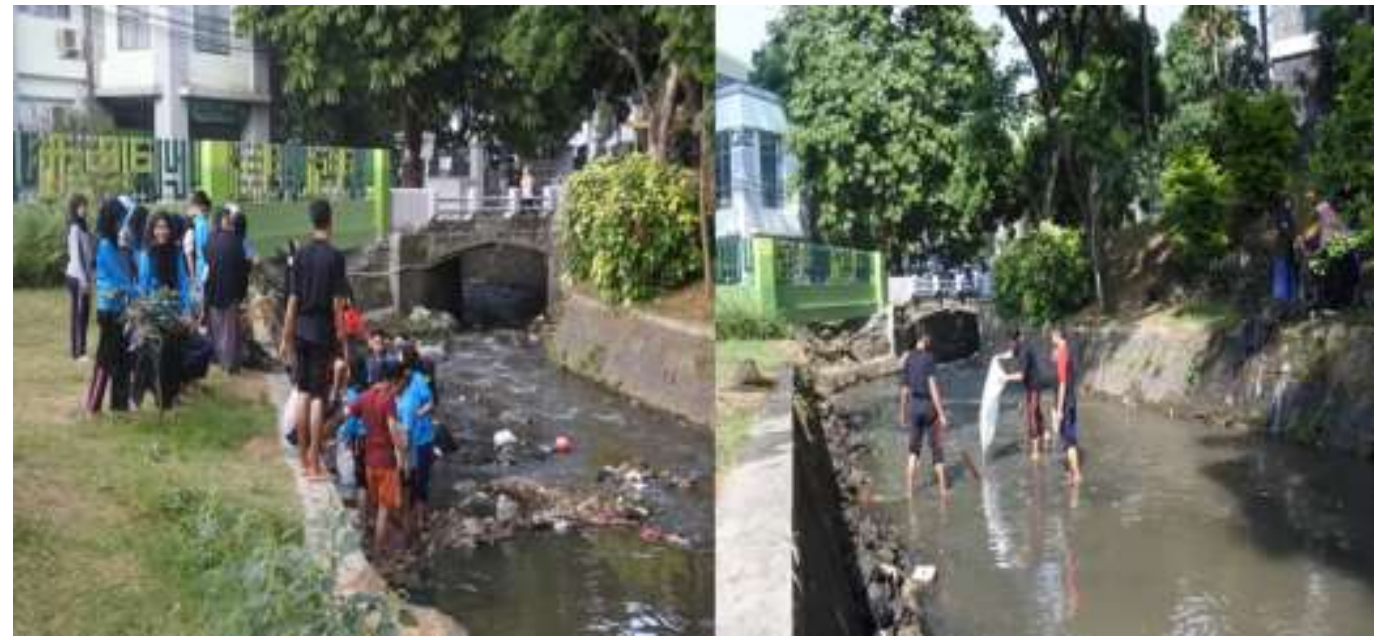

Gambar 3. Edukasi kepada mitra serta aksi nyata bersih sungai untuk menjaga ekosistem air yang lebih baik

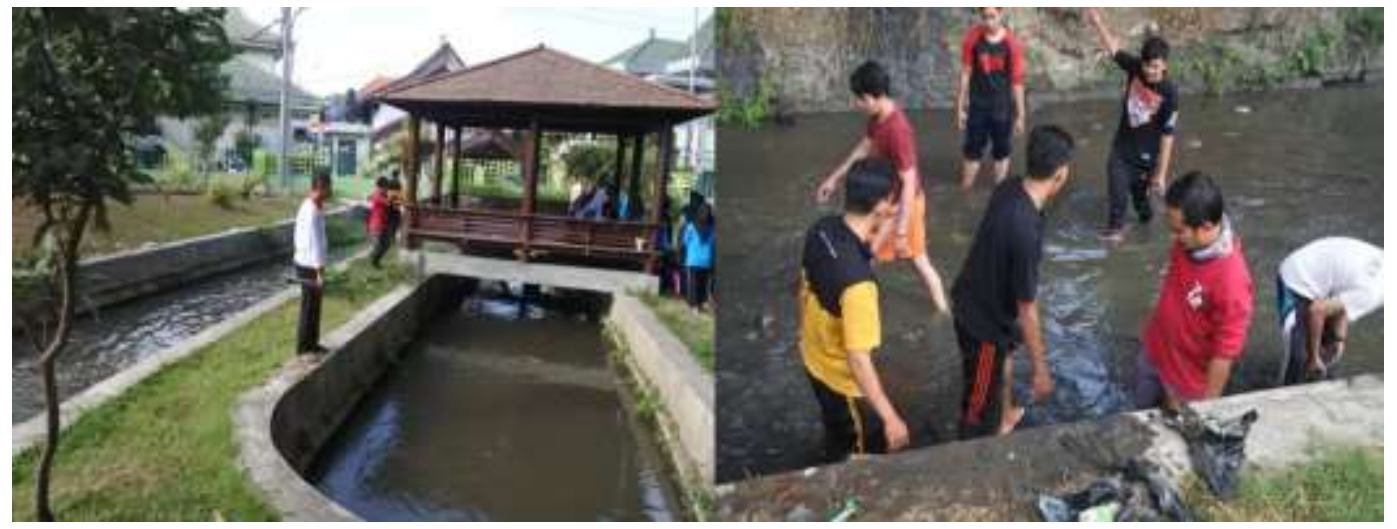

Gambar 4. Kondisi sungai yang sudah dibersihkan

Kombinasi metode diskusi dan ceramah dengan edukasi dan penggunaan media merupakan variasi metode dalam penyampaian materi kepada masyarakat sehingga peserta tidak jenuh atau bosan (Djamarah, 2000). Ceramah dan edukasi (teori maupun praktik) dalam sistem budidaya ikan dengan karamba. Keramba jaring apung adalah salah satu wadah budidaya perairan yang cukup ideal, yang ditempatkan di badan air dalam, seperti waduk, danau, aliran sungai dan laut. Keramba jaring apung merupakan salah satu wadah untuk penerapan budidaya perairan sistem intensif. Prinsipnya semua jenis ikan laut dan ikan air tawar dapat dipelihara pada keramba jaring apung (Abdulkadir, 2010).

Sistem budidaya keramba merupakan salah satu wadah atau tempat budidaya ikan dengan cara memanfaatkan aliran sungai yang paling ideal karena sirkulasi air selalu terjadi sehingga dalam proses aliran air dapat berjalan dengan baik. Keunggulan yang lain dengan sistem karamba adalah dapat mengurangi penyebaran benih penyakit akibat aliran air yang tergenang serta adanya predator ikan yang dapat mengurangi hasil produksi dari ikan yang dibudidayakan serta sistem karamba merupakan sistem yang paling ideal dalam budidaya yang diterapkan dalam daerah terbuka yaitu sungai. Sedangkan beberapa kekurangan dari sistem budidaya ikan dengan keramba adalah tambahan pakan hal ini dikarenakan ukuran karamba yang relatif kecil sehingga aktivitas pergerakan ikan dalam mencari makan sangat terbatas sehingga harus sering ditinjau untuk memastikan kebutuhan nutrisi yang dalam hal ini terkait pakan dapat terpenuhi. 
Tabel 1. Rangkuman kegiatan pengabdian masyarakat pada masyarakat sekitar Kelurahan Sumbersari

\begin{tabular}{|c|c|c|}
\hline $\begin{array}{c}\text { Jenis } \\
\text { Kegiatan }\end{array}$ & Uraian Kegiatan & Keterangan \\
\hline $\begin{array}{l}\text { Ceramah dan } \\
\text { Diskusi }\end{array}$ & $\begin{array}{c}\text { Masyarakat sekitar } \\
\text { Desa Sumbersari } \\
\text { beserta Mahasiswa } \\
\text { diajak berdiskusi } \\
\text { terkait pemahaman } \\
\text { aliran sungai untuk } \\
\text { budidaya ikan sebagai } \\
\text { upaya peningkatan } \\
\text { nilai ekonomi warga. }\end{array}$ & $\begin{array}{c}\text { Ceramah dan diskusi } \\
\text { diharapkan dapat } \\
\text { meningkatkan } \\
\text { pemahaman mitra } \\
\text { pengabdian. Potensi } \\
\text { budidaya ikan dengan } \\
\text { cara memanfaatkan } \\
\text { aliran sungai untuk } \\
\text { budidaya ikan hal ini } \\
\text { memiliki potensi yang } \\
\text { sangat baik karena } \\
\text { budiaya ikan dengan } \\
\text { aliran sungai } \\
\text { menggunakan sistem } \\
\text { karamba. }\end{array}$ \\
\hline $\begin{array}{c}\text { Pelatihan/Pra } \\
\text { ktek }\end{array}$ & $\begin{array}{c}\text { Mitra binaan terlibat } \\
\text { langsung dalam } \\
\text { tahapan budidaya ikan } \\
\text { dengan pemanfaatan } \\
\text { aliran sungai dengan } \\
\text { tahapan } \\
\text { membersihakan aliran } \\
\text { sungai dari sampah- } \\
\text { sampah yang terdapat } \\
\text { di sungai }\end{array}$ & $\begin{array}{c}\text { Mitra binaan } \\
\text { melakukan aksi } \\
\text { membersihkan sungai } \\
\text { dari sampah-sampah } \\
\text { yang terdapat disungai } \\
\text { untuk memberikan } \\
\text { nilai edukasi akan } \\
\text { pentingnya menjaga } \\
\text { kebersihan sungai. }\end{array}$ \\
\hline $\begin{array}{c}\text { Pendampinga } \\
\mathrm{n} / \\
\text { Evaluasi }\end{array}$ & $\begin{array}{c}\text { Mitra diberikan } \\
\text { pendampingan terkait } \\
\text { jenis jenis ikan yang } \\
\text { dapat dimanfaatkan } \\
\text { untuk budidaya ikan } \\
\text { dengan sistem } \\
\text { karamba dengan } \\
\text { memanfaatkan aliran } \\
\text { sungai. }\end{array}$ & $\begin{array}{c}\text { Mitra binaan } \\
\text { diharapkan berhasil } \\
\text { secara mandiri dalam } \\
\text { budidaya ikan sistem } \\
\text { karamba dengan } \\
\text { memanfaatkan aliran } \\
\text { sungai serta bersama- } \\
\text { sama menganalisis } \\
\text { permasalahan yang } \\
\text { terjadi dalam budidaya } \\
\text { ikan. }\end{array}$ \\
\hline
\end{tabular}

\subsection{Hasil Pelaksanaan}

Pemanfaatan aliran sungai untuk budidaya ikan memerlukan beberapa tahapan dalam proses pelaksanaan kegiatan antara lain. Melakukan sosialisasi terlebih dahulu terkait pentingnya menjaga ekosistem sungai untuk kehidupan makhluk hidup yang lebih baik yang kemudian dilanjutkan dengan aksi membersihkan sungai terlebih dahulu hal ini bertujuan untuk mengurangi sampah yang terdapat di aliran sungai.

Proses pembutan karamba memerlukan waktu kurang lebih 7 hari hingga karamba siap untuk digunakan dalam budidaya ikan. Tahap pemilihan bibit bertujuan untuk memastikan bibit ikan yang nantinya akan dipakai dalam budidaya memiliki ukuran antara $15-20 \mathrm{~cm}$ dan dalam kondisi yang sehat. Hal ini dikarenakan sistem budidaya ikan dengan karamba merupakan teknik budidaya ikan yang baru dicoba di masyarakat sekitar sehingga bibit yang dipakai memiliki ukuran yang relatif besar. Disamping itu kedalaman sungai menjadi salah satu faktor penting untuk keberhasilan dalam budidaya ikan dengan sistem karamba.

Menurut Wibisono (2005), menyatakan bahwa kedalaman suatu perairandidasari pada relief dasar dari perairan tersebut. Perairan yang dangkal kecepatanarus relatif cukup besar dibandingkan dengan kecepatan arus pada daerah yang lebih dalam (Bambang, 2011). Semakin dangkal perairan semakin dipengaruhi oleh pasang surut, yang mana daerah yang dipengaruhi oleh pasang surut mempunyai tingkat kekeruhan yang tinggi. Kedalaman perairan berpengaruh terhadap jumlah dan jenis organisme yang mendiaminya, penetrasi cahaya, dan penyebaran plankton. Dalam kegiatan budidaya variabel ini berperan dalam penentuan instalasi budidaya yang akan dikembangkan dan akibat-akibat yang ditimbulkan oleh kegiatan tersebut. 
Kedalaman perairan merupakan faktor yang diperlukan dalam kegiatan baik terhadap organisme yang membutuhkan kedalaman rendah sampai cukup dalam. Ikan nila tidak tergantung dari pakan buatan (artificial food), karena adanya aliran sungai dapat membawa sisa makanan yang dapat dikonsumsi oleh ikan tersebut, namun untuk mendapatkan hasil yang maksimal maka pemberian pakan secara berkala dapat mempercepat proses perkembangan dari ikan tersebut.

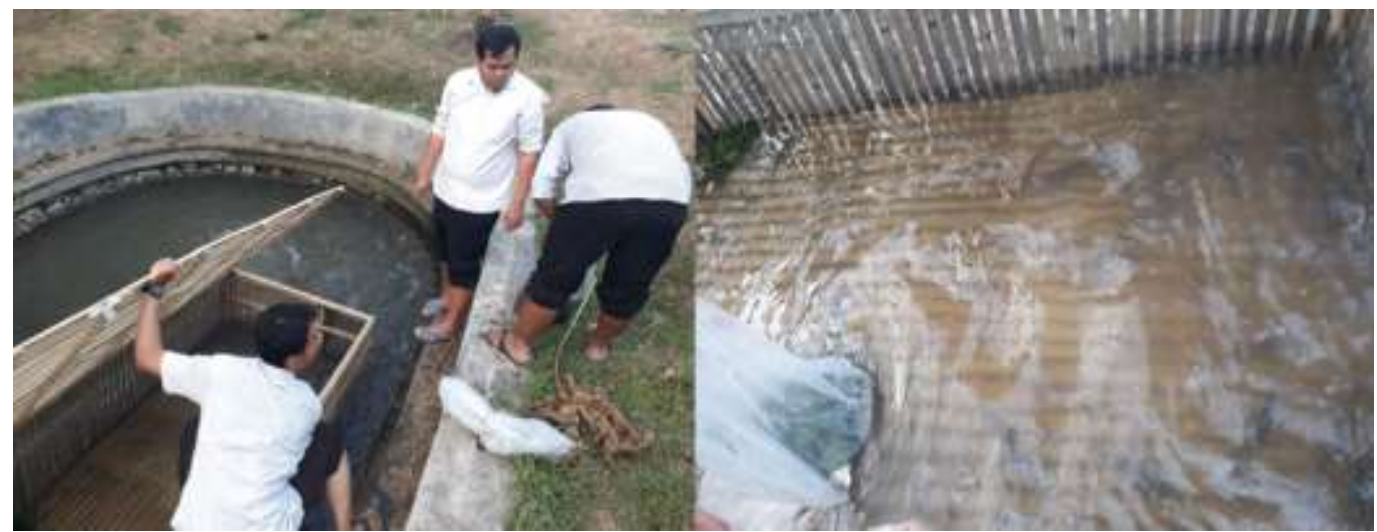

Gambar 5. Pemasangan karamba (a) dan pelepasan bibit ikan nila dalam karamba (b)

Tahap praktik atau demonstrasi yaitu mengajak mitra dalam pemasangan dan budidaya ikan dengan karamba (Gambar 5a). Dari beberapa hasil diskusi dengan mitra menujukkan bahwa budidaya ikan dengan sistem karamba dapat dipraktekkan langsung oleh masyarakat dan mengetahui teknik budidaya ikan dengan karamba dengan baik, tekait kelebihan dan kekurangan budidaya ikan dengan karamba. Praktik kegiatan budidaya ikan dengan karamba dimulai dengan penyiapan karamba dimana ukuran karamba disesuaikan dengan kondisi sungai dan banyaknya bibit ikan yang akan dibudidayakan. Tahap ke dua yaitu memilih bibit ikan dan ukuran bibit yang paling baik yang dapat beradapatasi dengan cepat hal ini bertujuan untuk mendapatkan hasil budidaya yang maksimal. Tahap yang ketiga yang paling penting adalah bagaimana praktik budidaya ikan dengan sistem karamba bertujuan untuk memberikan edukasi terhadap masyarakat akan pentingnya menjaga ekosistem aliran sungai tetap terjaga dengan baik. Evaluasi kegiatan diperoleh dari hasil kuisioner mitra dampingan yang memberikan tanggapan terhadap pertanyaan seputar budidaya ikan dengan keramba (Gambar 6).

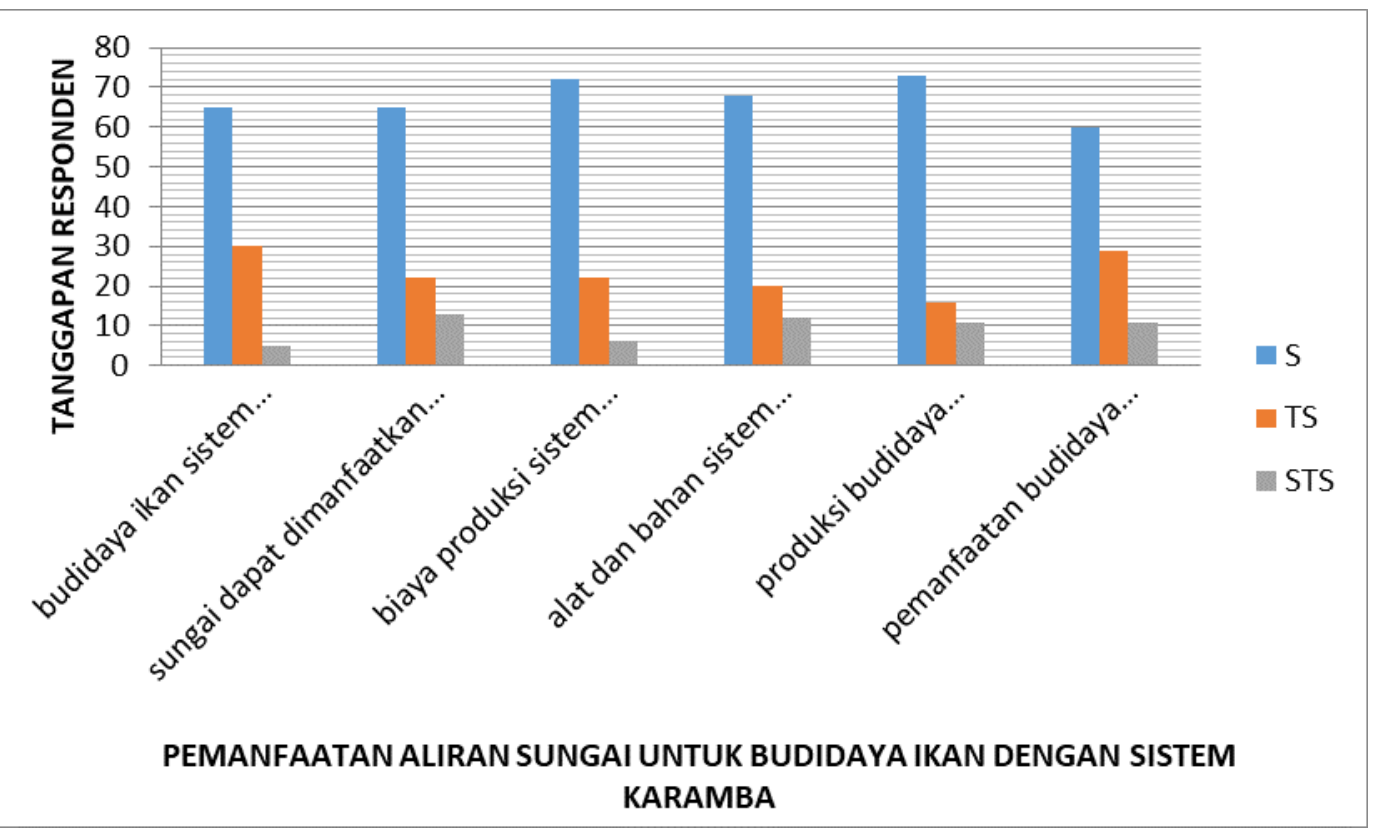

Gambar 6. Tanggapan responden tentang pemanfaatan aliran sungai untuk budidaya ikan sistem karamba 
Enam puluh lima persen mitra dampingan setuju bahwa sistem budidaya ikan dengan karamba mudah dilakukan, sisanya tiga puluh persen tidak setuju dan lima persen sangat tidak setuju. Sebanyak $72 \%$ responden setuju jika biaya produksi budidaya ikan dengan karamba terjangkau. Enam puluh lima persen responden menyatakan setuju sungai dimanfaatkan untuk budidaya ikan dengan karamba. $68 \%$ responden setuju jika alat dan bahan dalam proses pembuatan budidaya ikan dengan karamba mudah diperoleh dan $20 \%$ responden menyatakan tidak setuju dan 12 menyatakan sangat tidak setuju, terutama bahan seperti bambu dan ikan mudah diperoleh di kota atau kabupaten Malang. Tanggapan terhadap budidaya ikan dengan karamba sebagai usaha alternatif yaitu $73 \%$ responden setuju jika budidaya ikan dengan karamba sebagai usaha alternatif karena lebih mudah dilakukan meskipun $16 \%$ dan $11 \%$ responden menyatakan tidak setuju dan sangat tidak setuju. Enam puluh dua persen Responden setuju terkait Pemanfaatan budidaya ikan dapat menjadi aternatif untuk mengurangi sampah disungai, $29 \%$ dan $9 \%$ tidak setuju dan sangat tidak setuju terkait budidaya ikan dengan sistem karamba dapat mengurangi pembungan sampah disungai, karena penanganan terkait pembungan sampah disungai tidak bisa terselesaikan hanya dengan pemanfaatan aliran sungai untuk budidaya ikan dengan sistem karamba.

Tindak lanjut dari kegiatan pengabdian masyarakat yaitu didasarkan dari hasil evaluasi dan saran dari mitra. Pemanfaatan aliran sungai untuk budidaya ikan dapat dilanjutkan secara mandiri oleh mitra atau masyarakat sekitar Desa Sumbersari dalam upaya peningkatan nilai ekonomi serta mengurai pembuangan sampah kesungai dalam upaya menjaga ekosistem sungai tetap terjaga dengan baik.

\section{KESIMPULAN}

Peran sosial Responden masyarakat sekitar Desa Sumbersari dapat ditingkatkan melalui kegiatan pembinaan, pendidikan, pelatihan dan penyuluhan, salah satunya adalah Pemanfaatan aliran sungai untuk budidaya ikan dengan sistem karamba.

1. Metode yang digunakan meliputi kegiatan penyuluhan melalui ceramah, praktek langsung budidaya ikan dengan karamba, kemudian dilakukan evaluasi dari proses budidaya ikan dengan karamba. Hasil survei terhadap mitra menunjukkan bahwa sebagian responden mengetahui cara budidaya ikan dengan karamba, akan tetapi belum mengetahui bahwa aliran sungai juga dapat dimanfaatkan untuk budidaya ikan dengan sistem karamba.

2. Hasil praktek budidaya ikan dengan sistem karamba sebagian besar responden setuju setuju (73\%) jika budidaya ikan sistem karamba digunakan sebagai suatu ide usaha alternatif terkait pemanfaatan aliran sungai.

Rekomendasi dalam kegiatan pengabdian masyarakat berbasis PAR yaitu dilakukan dengan melibatkan lebih banyak mitra serta dilakukan secara berkesinambungan sehingga kebermanfaat dapat dirasakan baik oleh mitra maupun narasumber (tim pengabdi).

\section{UCAPAN TERIMAKASIH}

Ucapan terima kasih disampaikan kepada Masyarakat Kelurahan Sumbersari Kecamatan Lowokwaru Kota Malang bersama Bapak Ketua RT dan RW Setempat. Ketua LP3M Universitas Islam Negeri Maulana Malik Ibrahim Malang atas bantuan dalam Program UIN Mengabdi tahun 2019. Serta semua pihak yang telah membantu terlaksananya program pengabdian ini. Semoga Allah mencatat kebaikan semuanya dengan balasan yang lebih baik.

\section{DAFTAR PUSTAKA}

Abdulkadir. 2010. Keramba Jaring Apung. https://www.farraQafay.com. Diakses tanggal 21 November 2019.

Anonim. 2004. Biomanipulasi, paradigma baru dalam pengendalian limbah organik budidaya perikanan di waduk dan tambak

Anonim. 2008a. Pedoman pengelolaan ekosistem danau. Kementerian Lingkungan Hidup. Jakarta, 118 hlm.

Anonim. 2008b. Kegiatan kajian perhitungan daya tampung sungai 3 DAS dan 4 waduk prioritas. Badan Pengelolaan Lingkungan Hidup Daerah Provinsi Jawa Barat. Bandung, $127 \mathrm{hlm}$.

Anonim. 2009. Undang-Undang Republik Indonesia Nomor 32 tentang Perlindungan dan Pengelolaan Lingkungan Hidup. $110 \mathrm{hlm}$.

Djamarah, S.B. 2000. Guru dan Anak Didik dalam Interaksi Edukatif. Rineka Cipta. Jakarta.

Effendi, H. 2003. Telaah Kualitas Air Bagi Pengelolaan Sumberdaya dan Lingkungan Perairan. Kanisius. Yogyakarta.

Garno, Y.S. 2002. Beban pencemaran limbah perikanan budidaya dan eutrofikasi di perairan waduk pada DAS Citarum. J. Tek. Ling. P3TL-BBPT 3: 112-120.

Golmand, C.R., dan A.J. Horne. 1989. Limnology. McGraw Hill Company. New York.

Gowen, R.J. 1990. An assessment of the impact of fish farming on the water column and sediment ecosystems of Irish coastal waters. Report prepared for Departement of the marine, Ireland. Departement of the Marine, Dublin. 
Imanto, P.T., N. Lisyanto \& B. Priono. 1995. Desain dan konstruksi keramba jaring apung untuk budidaya ikan laut. Dalam Sudradjat et al. (Eds.). 1995. Prosiding temu usaha pemasyarakatan teknologi keramba jaring apung bagi budidaya laut, Puslitbang Perikanan. Badan Litbang Pertanian, Jakarta: 157-171.

Ismail, W. dan Wijono, A. 1995. Lingkungan laut: Pelestarian dan pengelolaannya bagi lahan budidaya perikanan. Dalam Sudradjat et al. (Eds.). 1995. Prosiding temu usaha pemasyarakatan teknologi keramba jaring apung bagi budidaya laut, Puslitbang Perikanan. Badan Litbang Pertanian, Jakarta: 157-171.

Keputusan Menteri Lingkungan Hidup. 1988. Pedoman Penetapan Baku Mutu Lingkungan. Jakarta, 49 hal.

Krismono \& Wahyudi, N.A. 2001. Analisis kebijakan pengelolaan keramba jaring apung sebagai salah satu kegiatan pengelolaan danau dan waduk. Dalam Analisis Kebijakan Pembangunan Perikanan. Pusat Riset Pengolahan Produk dan Sosial Ekonomi.

Mayunar, Purba, R. dan Imanto, P.T. 1995. Pemilihan lokasi budidaya ikan laut. Dalam Sudradjat et al. (Eds.). 1995. Prosiding temu usaha pemasyarakatan teknologi keramba jaring apung bagi budidaya laut, Puslitbang Perikanan. Badan Litbang Pertanian, Jakarta: 179-189.

Riset Kelautan dan Perikanan, Departemen Kelautan dan Perikanan. Jakarta, hlm. 75-85.

Sukadi, M.F. 2010. Ketahanan dalam air dan pelepasan nitrogen dan fosfor ke air media dari berbagai pakan ikan air tawar. J. Ris. Akuakultur, 5(1): 1-12.

Utojo, A.M., Rahmansyah dan Hasnawi. 2006. Identifikasi kelayakan lokasi budidaya rumput laut di kota baru, Kalimantan Selatan. Jurnal Riset Akukultur 1(3): 303 -318. 